\title{
Correction to: Automatic and Accurate Detection of Webshell Based on Convolutional Neural Network
}

Zhuo-Hang Lv, Han-Bing Yan, and Rui Mei

\author{
Correction to: \\ Chapter "Automatic and Accurate Detection of Webshell \\ Based on Convolutional Neural Network" \\ in: X. Yun et al. (Eds.): Cyber Security, CCIS 970, \\ https://doi.org/10.1007/978-981-13-6621-5_6
}

In the version of this chapter that was originally published, the acknowledgment of the NSFC Foundation was missing. The chapter has been updated to include these corrections. 
Open Access This chapter is licensed under the terms of the Creative Commons Attribution 4.0 International License (http://creativecommons.org/licenses/by/4.0/), which permits use, sharing, adaptation, distribution and reproduction in any medium or format, as long as you give appropriate credit to the original author(s) and the source, provide a link to the Creative Commons license and indicate if changes were made.

The images or other third party material in this chapter are included in the chapter's Creative Commons license, unless indicated otherwise in a credit line to the material. If material is not included in the chapter's Creative Commons license and your intended use is not permitted by statutory regulation or exceeds the permitted use, you will need to obtain permission directly from the copyright holder.

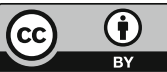

